\title{
Explaining Men's Entry into Female- Concentrated Occupations: Issues of Masculinity and Social Class
}

\author{
Ben Lupton*
}

This article seeks to add to an understanding of why some men enter female-concentrated occupations (and why the majority do not). Drawing on the results of in-depth interviews with 27 men in a range of occupations, I illustrate and interpret the complex and often contradictory ways in which men approach the notion of working in female-concentrated occupations and examine the impact that this has on their occupational outcomes. The data suggest that different attitudes to female-concentrated work cannot in themselves explain men's presence there. Consequently I explore, with particular reference to social class, the context in which attitudes around gender, work and occupational destinations, are framed. I conclude that men's entry to female-concentrated occupations may best be approached, not as an issue of 'masculinity' but as one of social mobility operating within a gendered labour market.

Keywords: men, masculinities, social class, social mobility, gender

\section{Introduction}

$\mathrm{T}$ his article is concerned with understanding men's entry into (and avoidance of) occupations in which women are in a majority. This is an important issue for two reasons. Firstly, because the crossing of gendered work boundaries illuminates the processes by which occupational segregation is maintained or reduced. Secondly, as Hayes (1986) has pointed out, because a significant reduction in the levels of occupational segregation by gender requires not only that women move into male-concentrated occupations, but that men move into female-concentrated occupations (without displacing the majority of women there). For these reasons, we could benefit from a better understanding of why men (and which men) do, and do not, enter

Address for correspondence: *Manchester Metropolitan University, Postgraduate Office, Aytoun Building, Aytoun St, Manchester UK M1 3GH, e-mail: b.lupton@mmu.ac.uk 
female-concentrated occupations, and this article seeks to make a contribution to this understanding.

There has been a relatively recent growth in academic interest in men who

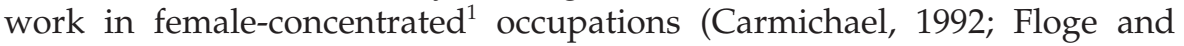
Merrill, 1986; Galbraith, 1991; Heickes, 1991; Isaacs and Poole, 1996; Kvande, 1998; Pringle, 1988, 1993; Segal, 1962; Williams, 1995). These studies have provided a good understanding of men's experience in such occupations. Researchers have also shown that there are patterns of movement by men into female-concentrated occupations. For example Morgan (1992) and Bradley (1993) have drawn attention to the different circumstances in which men move in to female-concentrated occupations - as 'tokens', or as part of an 'infiltration' and 'invasion' - and to the different effects that these processes have. However, much less is known about why men enter femaleconcentrated occupations.

Two main approaches can be identified in studies that have attempted to tackle this question. The first has sought to base explanations of men's entry to female-concentrated occupations on the characteristics and preferences of individual men (Dabbs et al., 1990); the second has focused on the labour market processes through which jobs are 'allocated' (Williams and Villemez, 1993). Later in the article I review this literature and draw attention to the limitations of the first approach as the sole basis for explanation. My own study, reported in this article, is located within the second of these approaches, in seeking explanation in an understanding of the broader social context within which occupational outcomes are framed. It differs, however, from the existing literature in seeking to ground this understanding in the experience of individual men rather than in labour market or survey data.

I interviewed 27 men working in a range of occupations in the United Kingdom. The interview data illustrate the complex and often contradictory ways in which men approach the notion of working in female-concentrated occupations. I suggest that the differences in the way in which men make sense of this transition are insufficient to account for the fact that some men enter these occupations and most men do not. The data indicate that social class may be one of the keys to explaining the 'gender-typing' of men's occupational outcomes and I illustrate and explain how and why this might be the case. I conclude by suggesting that men's entry to female-concentrated occupations may best be understood as an issue of social mobility operating within the context of a gendered labour market.

\section{Men's experience in female-concentrated occupations}

There have been two main themes in the literature on men working in female occupations - the first that, in Williams' words $(1995$, p. 80) 'men take their gender privilege and sexual power with them' into women's work and thus 
represent an advantaged, rather than an oppressed minority; the second that 'masculinity' comes under scrutiny for men when they cross gendered work boundaries (Cross and Bagilhole, 2002; Lupton, 2000). Both these themes are likely to be useful in understanding why men might enter or avoid femaleconcentrated occupations and a brief summary of the literature around these is an apposite starting point. Before embarking on this it is also helpful, briefly to consider how the terms 'masculinity' and 'masculinities' are to be used. I take the plural 'masculinities' to be preferable and more powerful analytically, reflecting as it does the possibility of different and changing masculinities and incorporating the idea that they are 'done' (not possessed) by men and women. The singular 'masculinity' is used, as above, in its colloquial sense as an attribute held by a member of the male sex. It appears as such in some of the literature that I draw on and critique, and it is also the term used by many of my respondents. Where I use 'masculinity' I do so to capture this meaning. ${ }^{2}$

\section{Men's advantages in female-concentrated occupations}

There is considerable evidence that men who enter female-concentrated occupations benefit from their minority status (Floge and Merrill, 1986; Gutek and Groff Cohen, 1992; Heickes, 1991). Three main (interlinked) phenomena have been identified. Firstly, men progress more quickly than women to senior positions - riding the 'glass escalator' (Williams, 1995; Kvande, 1998). The effects of this process are apparent in the vertical segregation that sees a higher proportion of men in the upper echelons of femaleconcentrated occupations than in these occupations as a whole, for example in primary-school teaching where men comprise 14 per cent of all teachers, but 41 per cent of head teachers (Department for Education and Skills, 2001). There is evidence that men avoid discrimination by opposite sex superiors (Williams, 1995), are 'fast-tracked' by senior managers, male and female (Allan, 1993; Benton DeCorse and Vogtle, 1997), and benefit from the reconstruction or re-evaluation of work that occurs when they, rather than women, undertake it (Pringle, 1988, 1993).

Secondly, men may be channelled into particular specialities in occupations that are regarded (by themselves and by others) as more appropriate to their gender, and that often carry greater rewards and prestige - which may be both a cause and a consequence of their gender associations. Examples of this process are the disproportionate presence of $\operatorname{men}^{3}$ in mental-health nursing (Williams, 1995), in employee-relations roles in the personnel profession (Long, 1984), in secondary or upper-age primary school teaching (Allan, 1993) and in academic and business libraries (Williams, 1995). However, as Williams and Allan have pointed out, neither 'fast-tracking' nor 'channelling' necessarily meets the expectations of all men. As these authors and Sargent (2000), report, men may as a result be discouraged from entering an 
occupation that interests them or they may be eased out of it. As Williams puts it, extending the analogy, 'like being on a moving escalator, they [men] have to work to stay in place' (1995, p. 87).

The third advantage relates to remuneration. Williams (1995) and England and Herbert (1993) have shown that men are paid more than women in female-concentrated occupations. This would follow from the processes described above. However both sets of authors show that men in femaleconcentrated occupations earn less than men in comparable 'male' ones. While men who enter female-concentrated occupations may maintain their pay advantages over women, they may, however, remain disadvantaged in relation to other men.

\section{'Difficulties' for men in female-concentrated occupations}

There has been an increasing recognition that men may experience a challenge to their masculinity, both through working alongside women and from performing a role that women normally undertake. As Williams argues, this may be a more fundamental challenge than the one women face when moving into traditionally male occupations:

[W]hile many women may enjoy the 'feminine' aspects of their work their femininity is not contingent on proving themselves competent in 'genderappropriate' work, which is often how masculinity is experienced by men. (1993, p. 15)

\section{Cockburn has suggested that}

the handful of men who cross into traditional female areas of work at the female level will be written off as effeminate, tolerated as eccentrics or failures. (1988, p. 40)

None of these would be a valued identity in the context of the hegemonic constructions of masculinity prevalent in western societies (Carrigan et al., $1985)$ and there is considerable evidence that men working in femaleconcentrated occupations suffer these stigmas (Allan, 1993; Benton DeCorse and Vogtle, 1997; Carmichael, 1995; Heickes, 1991; Morgan, 1992).

Men's responses to these challenges often reinforce the gender order rather than subvert it. Masculine identities, like other identities, 'constantly have to be constructed, negotiated and reconstructed in routine social interaction' (Collinson and Hearn, 1994, p. 8), particularly in an environment such as a female-concentrated occupation where they are placed under challenge. One strategy that men use is to be demonstrably careerist, emphasizing the career prospects rather than the job (with its gendered connotations), or even to disassociate themselves from the job altogether when outside the workplace (Williams, 1995). A second is to identify with other more powerful male groups (Floge and Merrill, 1986), for example, male nurses associating with 
male doctors; seeking, as it were, hegemonic masculinity by association. A third strategy is to represent the work as more 'masculine', even to the extent of re-titling the job to avoid the non-masculine associations (Pringle, 1993). This may go further and involve doing the job differently, prioritizing the more 'masculine' elements, for example the technical, physical or managerial aspects (Lupton, 2000; Williams, 1995). Seeking out 'masculine' specialities and avoiding 'feminine' ones may also form part of such a strategy (Williams, 1995). ${ }^{4}$ The challenge to sexuality may be dealt with by emphasizing one's heterosexuality (Morgan, 1992), or engaging in discourses that reinforce masculinity in relation to others, such as women and homosexual men (Barrett, 1996), or by 'impression management' (Thompson and McHugh, 1990), for example, through dress (Collier, 1998). ${ }^{5}$

In summary, the literature suggests that men carry gender advantages with them into female-concentrated occupations: in other words; they maintain their privileges over women in those occupations. However the evidence is that they are disadvantaged in relation to men in other occupations, in terms of financial rewards, status and prestige. Furthermore, such men may experience a misalignment of their gender and occupational identities and expend a great deal of energy on 'identity work' to resolve this (Lupton, 2000, 2003).

\section{Understanding men's entry to female-concentrated occupations}

There have been two main approaches to explaining men's entry to (and avoidance of) female-concentrated occupations. One approach has been to concentrate on preferences for, and decisions to enter, such occupations identifying the balance of factors that may attract or repel men from choosing female-concentrated work. A second approach has been to concentrate on the labour market processes which frame occupational outcomes and to explain, on the basis of these, why some men are more likely than others to 'end up' in female-concentrated occupations. These are characterized for the purpose of the following discussion as 'individual' and 'social' explanations, though this is not to suggest that these are necessarily mutually exclusive approaches.

\section{Approaches based on individual characteristics and preferences}

Hayes (1986) provides a summary of the factors that might influence men both positively and negatively in considering entry into a femaleconcentrated occupation. When considering this approach it is important to recognize the limits of a straightforward dichotomy and to be aware of the possibility that individual men may be influenced both positively and 
negatively. Nonetheless, Hayes' analysis corresponds closely to the reported experiences of men working in these occupations, as discussed above (Lupton, 2000; Williams, 1995). Thus, on the negative side Hayes cites the lack of status and rewards in female-concentrated occupations, the challenges to masculinity, and evidence of parental and school discouragement of boys considering female-concentrated occupations. The attractions of female-concentrated work are less obvious. As Jacobs (1993, p. 49) suggests, 'men would have little reason to choose female dominated jobs' particularly 'when more financially rewarding jobs are available' and when they have the added disincentive of the challenge to their masculinity presented by female work, which Jacobs terms the 'prestige penalty'.

However, as Hayes argues, it is also possible to identify 'pull' factors of female-concentrated occupations for men; they (arguably, drawing on human capital theory [Anker, 1998]) require less 'commitment', are less demanding on time and they may be attractive to men who wish to prioritize areas of their life other than a career. Equally, heterosexual and bisexual men may be attracted by the sexual opportunities afforded by working predominantly with women or by the 'glass escalator', or they may conceive of female-concentrated occupations as an easier way to the top, free from competition from other men. Finally, Hayes cites the fact that men may be drawn to female-concentrated occupations because they offer the job characteristics that are congruent with their vocational interests. This is a strong theme in the accounts of Williams' (1995) respondents, and it is certainly plausible that some men become, say, librarians, because that kind of work is attractive to them personally. However, even if we accept that one's destination is taken to indicate such a preference (a questionable assumption), it would not explain why some men want to do these jobs, yet most do not.

There is also a strand of research that suggests that some men are more likely than others to choose female-concentrated work because they are physically or psychologically distinctive. Some writers (Dabbs et al., 1990; Govier and Bobby, 1994) have reported a relationship between physical attributes that are known to differ between men and women (such as testosterone levels and performance in dichotic listening tests ${ }^{6}$ ) and occupational outcomes; in each case showing that men with less 'masculine' attributes are more likely to be found in female-concentrated occupations. Others have explored relationships between psychological measures of masculinity and the presence of men in female-concentrated occupations (Galbraith, 1991; Hayes, 1989; Jome and Tokar, 1998; Lemkau, 1984; Lobel, 1994; McLean and Kalin, 1994; O'Heron and Orlofsky, 1990; Tokar and Jome, 1998) and though the picture is not wholly consistent there is some evidence of a relationship between masculinity and occupational outcome. ${ }^{7}$ Nonetheless, there are two reasons to be cautious about this. Firstly, masculinity is regarded here as an attribute when other writers (Kerfoot and Knights, 1993) have demonstrated that it is much more usefully regarded as something that is done and, as noted earlier, more 
usefully referred to in the plural. The consequent measurement process fixes attitudes and behaviour as distinctively 'masculine' or 'feminine', or even as 'male' or 'female'. Secondly, a limitation of this approach is that it conflates outcome with preference. Differences in preferences can explain differences in occupational distribution only when people are free to choose their occupations and, as many writers (such as Anderson, 1998; Roberts, 1981) have pointed out, this is very often not the case.

\section{Approaches based on social patterns and processes}

There have been several studies suggesting the need to go beyond a focus on men's preferences and choices. Jacobs (1993) has suggested that men enter female-concentrated occupations through a 'revolving door'. In other words, the desire of individual men to work, or not to work, in a femaleconcentrated occupation changes over time and, while the aggregate number of men working in female-concentrated occupations remains stable, individual men move in and out of such occupations. ${ }^{8}$ Williams (1995), like Jacobs, rejects the notion of a direct relationship between early career aspirations and one's subsequent destination. Most of her respondents made a late decision (at college or even in mid-life) to enter a female-concentrated occupation and did so through a combination of circumstances. She reports that her interviewees were not 'driven' in their career behaviour; on the contrary, they tended to lack direction until they were influenced by their friends or changes in circumstances to consider 'non-traditional' work. This finding has been supported in relation to elementary-school teaching in the US by Brookhart and Loadman (1996) and Benton DeCorse and Vogtle (1997).

Williams and Villemez (1993) identify a 'trap door' rather than a 'revolving' one. They found that the majority of men who entered femaleconcentrated occupations were not there by choice and that, of those men who had sought a female-concentrated job, many were not successful. If, for men, entry to female-concentrated occupations is a matter of consequence rather than design, and if working in such occupations is considered as a disadvantage for men, then one might expect that the factors usually associated with labour-market disadvantage (minority ethnic status, lower social class) would be disproportionately found amongst men in such occupations. Support for this comes from Williams and Villemez (1993) and Lemkau (1984) in relation to race and from Lemkau (1984), Kvande (1998) and Lupton (2003) in relation to social class. In both cases there appears to be a paradox - men from ethnic minorities and lower social class groups were more likely to express an aversion to female-concentrated work, but were also more likely to find themselves there. However, the only large-scale survey (Hayes, 1989) concluded that men in female-concentrated occupations (in the US) were no more likely to come from lower socio-economic or minority ethnic groups than were other men. 


\section{Research design and methodology}

The literature provides several clues as to why some men might enter femaleconcentrated occupations. However it is not conclusive and leaves a number of important questions unanswered. From the literature on men's experiences in female-concentrated occupations we can draw plausible inferences about what men might find attractive or otherwise about them, but this could only explain the distribution of men in the labour market if it can be established that men are aware of these features in forming their preferences and are then able to convert these preferences into outcomes. Furthermore, this focus would not in itself offer an explanation as to why it is that some men are more likely than others to be drawn to female-concentrated occupations. To do this one would have to invoke essential differences between men (an avenue critiqued above) or differences in the social context in which preferences are formed and realized.

It is this latter approach, focusing on issues of social context, which informs the design of the study reported in this article. The study aims to develop not only a deep understanding of how and why men construct the notion of working in female-concentrated occupations, but a clear understanding of the social context in which that takes place and the wider context which influences the occupational destinations of men. The approach draws on a critical realist stance (Bhaskar, 1989; Collier, 1994), accepting a connection between men's actions and perceptions in relation to entering femaleconcentrated work and the underlying social structures in which both are grounded.

To achieve these aims, 27 in-depth interviews were conducted in the United Kingdom between 1999 and 2002, with men in seven occupational groups. The purpose of the interviews was to uncover respondents' understanding and experience of female-concentrated work, to explore the derivation of these constructions and to draw on them to analyse the broader processes at work in framing occupational preferences, choices and outcomes. Three of the occupations included in the sample were femaleconcentrated - primary-school teaching, human-resource management and librarianship; and for purposes of contrast and comparison, three were not so - law, computing and accounting. ${ }^{9}$ The seventh occupation was clerical work (female-concentrated); four men in this occupation were interviewed as part of the pilot study and I draw on their responses in reporting the results of the study here. With the exception of clerical work, all the occupations are graduate-entry occupations and open to those with a first degree in any subject. This allowed a broad level of comparability between the men in terms of their educational experiences and also meant that their career 'decisions' had not been constrained by earlier educational choices. All the men had recently entered these occupations or had undertaken a course of study leading to entering them, which had the advantage that their recollections of the process 
of choosing them or arriving there were relatively recent. Interviewees were identified through personal and professional contacts and in most cases were interviewed at their place of work or study.

Given the potentially sensitive nature of some of the subject matter of the interviews, it was necessary for ethical reasons, and to facilitate an open exchange, to provide the respondents with assurances of anonymity and confidentiality. I also explained clearly my purpose in interviewing them, both at the time of making contact with them and at the outset of the interview. I took time to put interviewees at ease, particularly by allowing them to talk generally about their life and careers before addressing the research questions more directly. I was also able to tell them that I had spent some time working in a female-concentrated occupation, which, as Cross and Bagilhole (2002) have suggested, might make the men in such occupations more comfortable in discussing their experiences. My impression was that the respondents, particularly those in the female-concentrated occupations, were keen to engage with the subject of the research. For some it was a chance to talk about issues that they had thought about a great deal but had not had an opportunity to discuss. Other respondents told me that the discussion had been a useful process in that it had given them an opportunity to think about their lives and careers, choices and constraints, in a way that they had not done before. At the end of the interviews I asked the respondents if they had further questions or concerns and whether there was anything they would like to add. Many interviewees continued to talk about the issues and my research after the formal interview had finished. Some asked me about my research findings to date and we were able to discuss possible explanations.

However, the interview data need to be considered with reference to the context in which it was recorded (Collins, 1998; Deutscher, 1984). My presence as a researcher and as a man necessarily influenced the nature of the encounter and the substance of the exchange (Denzin, 1989; Padfield and Proctor, 1996; Williams and Heickes, 1993). Regarding the first point, a number of respondents sought assurance, in discussions after the interview, as to whether they had 'given me what I wanted'. This raises questions about whether respondents were striving to present themselves in a positive light and responding in what they may have perceived as a 'politically correct' way. However, the apparent frankness, level of detail and often self-critical nature of their responses provide some reassurance here. The influence of my gendered presence is also significant and raises the issue of whether and how this presence may have generated particular types of responses and precluded others (see Schwalbe and Wolkomir [2001] and Lupton [2003] for a discussion of this issue). Given this, it is important to keep the gendered context of the interview in mind in interpreting the data that I present below.

The data were analysed through a process of familiarization, identification of connections and themes, coding and recoding (Coffey and Atkinson, 1996). 
I commence the report of this analysis by exploring men's views on the prospect of working in female-concentrated occupations. I move on to examine how the interviewees' background and upbringing influenced both the development of their views on working in female-concentrated occupations and on the prospect of them choosing or 'ending up' in such an occupation.

\section{Men's views on working in female-concentrated occupations}

The accounts of the interviewees revealed a detailed and subtle understanding of both the difficulties and advantages of entering female-concentrated work.

\section{Negative views of working in female-concentrated occupations}

A concern expressed by many of my respondents (as in other studies, such as Cross and Bagilhole, 2002) was that their masculinity and heterosexuality would be brought into question by working in a female-concentrated occupation.

If I had decided to be a nurse, say, then I would have had extra barriers than the usual ones, things like 'why are you doing a woman's job?' ... you would probably end up getting the rip taken out of you if I ended up doing a job like that. (Wayne, trainee accountant)

I wouldn't have a problem of who I worked with ... it's just how other people would perhaps think of me... making assumptions about me when I would rather they met me on a rather neutral footing (Norman, trainee solicitor)

Norman went on say that he would worry that people would think he was homosexual if he worked in a female-concentrated occupation. Norman's use of the word 'neutral' in the above quote is interesting. My interpretation is that, for him, the existing gendered order of things is 'neutral', and is therefore unobjectionable and not questioned, whereas departures from it (like men working in female-concentrated occupations) are problematic. Only if he 'places himself' in a female-concentrated occupation would he 'become' gendered and sexualized.

Scott shared this discomfort at the prospect of working in a femaleconcentrated occupation. He found that his concern over perceived stigmas and their effect on his own thoughts and behaviour existed despite his own outwardly liberal position on issues of sexuality as expressed elsewhere in his interview:

I don't know why it is: it is an arrogant thing, or just a masculine thing, I don't know what it is. Heterosexual males don't want to be confused with 
homosexuals by virtue of being in a homosexual post, for whatever reasons. (Scott, trainee accountant)

The reference to a 'homosexual post' is particularly interesting. For Scott, jobs are not only gendered but are sexualized too. Scott also articulated the difficulties constructed by discourses around male 'perverts' working with children (Allan, 1993; Sergeant, 2000); a view which also emerged in the comments of Niall, a primary-school teacher who worked with very young children. Here he describes the reaction from parents when he first taught their children:

[T] hey looked me up and down: 'it's a man'. You can see these things [in their faces]. 'What's wrong with him?' (Niall, primary-school teacher)

Moving into female-concentrated occupations, then, represents a violation of the horizontal gendering (and sexualizing) of work. For some men it also violated vertical gendering. This is revealed in comments by Scott and Mel:

[I]n a lot of these jobs that are traditionally feminine, they tend to be dominated by a step-up level of blokes, and I think I would feel quite frustrated in those jobs ... being dominated by them [other men]. (Scott, trainee accountant)

I think a lot of people would be fairly insecure having a male working as a secretary ... I think some of the males would find it more difficult to order around, to sort of get one of their fellow males, I suppose, to do the menial jobs. I think that they would find it rather embarrassing. ( $\mathrm{Mel}$, trainee solicitor)

Collinson and Hearn $(1994,1996)$ have highlighted the pervasive gendering of management and the 'association of men, power and authority' in the workplace (1996, p. 4). The comments above illustrate very graphically the logical extension of that association in the context of the gender/power relations inherent in vertical occupational segregation. Here, to be managed is to be feminized.

It is also interesting that the respondents in female-concentrated occupations recognize, and in some cases subscribe to, the stereotypes around masculinity and sexuality that apply to men in their occupations.

[Y] ou do get a lot of comment definitely, that it [librarianship] is a woman's job ... It does sound sort of nancy, really: there is that connotation. (Neil, librarian)

I suppose if you asked a man in the street what they think male librarians are like, they might think, 'oh, a bit soft, a bit of a sissy, always got excused games at school', you know; 'cold on his chest' . . and there is a couple like that here. (Dom, librarian) 
The latter respondent was so acutely aware of the stigma associated with men in his profession, the idea that they were something less than a 'normal' man, that he sometimes denied being a librarian - an approach also reported by Cross and Bagilhole (2002):

This is going to sound terrible, there have been times when I've come across old associates from my old days in X-town in the pubs, when they've said, 'what are you doing now?' and I'll say, 'oh well, I'm a porter' — instead of a librarian. (Dom, librarian)

\section{Potential attractions of female-concentrated work}

Whilst there is substantial evidence in the study that men anticipate as well as experience that their masculinity and sexuality will be questioned in female-concentrated occupations, there was also evidence that some men perceive advantages to such work (Hayes, 1986). Here Maurice identifies and comments on the 'glass escalator' (Williams, 1995):

[Y]eah, there is definitely that attitude and the whole glass ceiling thing about men becoming headmasters is definitely true ... the only male there apart from the caretaker: it is such a cliché, but it is definitely true ... when people say you are likely to get a job that is much better paid, you are not exactly that worried about it. (Maurice, trainee primary-school teacher)

Maurice articulates the idea that men's promotion prospects will be better in an environment where women represent most of the competition, but the 'fact' that he will be promoted more easily is taken for granted and not explained. Niall offers an insight into this:

[W] omen teachers go off and have children and men stay in the system ... so if you are a governing body you might say, 'Well, he's a man, his career is mapped out: he's not going to get pregnant, get in a relationship, so it's more stable'. That's not necessarily correct but that is what happens. (Niall, primary-school teacher)

A third respondent, Faisal, ${ }_{10}^{10}$ provides an excellent example of how tokenism might work to the advantage of male minorities (Floge and Merrill, 1986). Here he makes explicit reference to how Kanter's (1977) notion of 'visibility' might help him as a man in a female-concentrated occupation:

It might have been just that bit more easier if you were a male ... stand out a bit more, be seen as being different I guess ... I felt there might have been organizations where they might feel they might need a male in HR alongside the women because they've always been female-dominated: some organizations might need a balance and so on. I never felt just because it is a profession where it's mostly female, I shouldn't go there: I've never felt that. I've felt the opposite because I felt it would probably give more opportunities. (Faisal, human resources officer) 
Faisal's use of the word 'balance' is also instructive. Male advantage in female-concentrated occupations is rationalized as a process of seeking equity and can therefore be experienced as legitimate and unobjectionable.

\section{Understanding men's entry into, and avoidance of, female-concentrated occupations}

The men I talked to generated and reproduced a range of discourses around the idea of working in female-concentrated occupations. Some of these are likely to have the effect of attracting men towards such work: many of them are likely to do the opposite. The balance of the evidence is that, all other things being equal, they are likely to have a negative effect on men's propensity to seek out such work. However it is not at all clear that these views and preferences could account for the occupational distribution of men, even if they were taken to be representative of the views of a wider population from which the interview sample was drawn. Firstly, the interview data suggest that men who work in female-concentrated occupations are at least as likely to draw attention to the difficulties that such work provides as men who have avoided such occupations, although this may to some extent be the result of experiences in these occupations heightening an awareness of such issues. Secondly, the differences in the way in which female-concentrated work was constructed could explain the presence of some men in such occupations only if it could be shown that they had chosen these occupations on this basis. While some men (like Faisal) describe themselves as having entered or avoided female-concentrated occupations on the basis of these issues, others find themselves in female-concentrated work despite the profound difficulties that this creates for them.

Clearly, other explanations are needed. In the remainder of the article I explore one of these; the relationship between social class of origin ${ }^{11}$ and gendered occupational outcomes. Concentrating particularly on the responses of a number of men who identified themselves as being from a working-class background, ${ }^{12}$ I will explore how this affected the way in which they construct the gendering of work and how it impacted on their occupational outcomes. I will seek to show why some of these men work in femaleconcentrated occupations despite the difficulties that violating the connections between masculinity and work create for them.

\section{Masculinity, social class and occupation}

Notions of gender-appropriate work for a man were deeply ingrained in the thinking of many of the working-class respondents, as the following extracts illustrate: 
I know that my step-dad is a real man's man, I suppose. He works as sort of a labourer and he's got certain views about men in women's jobs... well, he has more or less said to me that my job is a woman's job, really ... he's one of these people who sort of sees white-collar jobs under managerial positions as women's... whereas your blue-collar job is for men. (Malcolm, clerical worker)

It [being a librarian] is not really conforming to the stereotype of a working-class man's job: that the working-class man is a man; he goes out, he digs coal with his teeth and then he comes home and expects his tea on the table, a bit of slap and tickle and then put the 25 kids to bed, or whatever. He [a librarian] doesn't conform to the stereotype ... it's not an accepted man's role, it's not heavy, it's not hard: it's white collar, it's something which doesn't take any guts, any danger whatsoever. (Neil, librarian)

'Therefore', librarianship is, as Neil puts it, a 'woman's job'. It was clear from Neil's tone that he regarded the use of this term by others as derogatory rather than merely a comment on the numerical gender balance in the occupation.

Both Malcolm and Neil show an acute awareness of the contrast between their own occupation and the masculine roles expected of them in their backgrounds. Dom also shows this awareness but is distinctly less comfortable with the position that it leaves him in. Here Dom reflects on how being a librarian had affected his view of his own masculinity:

I've probably not felt like a proper man as a result of being a librarian ... suppose I can only escape my roots to a certain extent ... I dunno, I want to feel that I have got that man's right ... my family are very working-class and the majority of them have always been in physical, traditional male jobs, and I suppose there's a bit of that still in me. I think that - maybe sometimes I do think - I would have liked to have done more masculine, fulfilled a more masculine role but, I mean, a lot of men are like that. We are daft creatures at times. It's like, if you do a bit of DIY at home you can be absolutely useless, but you still try and fix it, or you like to think that you can fix it. I don't think any of us like the fact when we have to admit defeat and get a man in. (Dom, librarian)

It is interesting that Dom, like Neil and Malcolm above, describes having a physical job as a man's 'right', something that is afforded to a man on account of his gender and allows him to demonstrate his masculinity. There are strong echoes here of the accounts in Willis (1977) and Collinson (1992) of working-class men's definitions of 'real' work, and the association of physical labour with masculine identities. The DIY example is another interesting illustration of the issue of compromised masculinity. In this discourse, doing jobs around the house is an expression of masculinity and an inability to do so is an admission of failure as a man. What is telling here is that Dom does 
not say, 'get a plumber in' or, 'get a decorator in': he says, 'get a man in'. The ultimate humiliation if your own masculinity is inadequately demonstrated is to have to buy in someone else's.

Nonetheless, both Dom and Neil suggest that librarianship is a relatively common destination for first-generation male working-class graduates,

I am from a working-class background and my [male] colleagues I would say the majority of them . . . are, but I think it is part of the explosion in the education thing ... but I suppose it's one of those bridging careers. I suppose it is neither middle-class, it's not really working-class, it's nothing really... but it is strange that on my [librarianship] course everybody [the male students] was from a similar background, all from places like Liverpool, Leeds, not country places either, so big major industrial places or industrial towns (Neil, librarian)

Well you know [male librarians] they are not train-spotters, they are just ordinary lads, you know, you can have a chat with them about football, you can go for a drink with them, the way they carry themselves, the kind of clothes they wear, it's all normal. (Dom, librarian)

Neil locates librarianship very precisely on his social landscape. What is particularly interesting, however, is the way in which he articulates its ambiguous position in relation to working-class masculinities - 'it's nothing really'. Librarianship, as a female-concentrated occupation, appears to inhabit a no-man's land, between physical 'man's work' on the one hand, and middle-class 'career' work on the other. This is an awkward place for a man to be, particularly a working-class man; denied the opportunity to reinforce notions of masculinity through physical labour on the one hand, or through status and financial reward on the other. This is compounded by the fact that librarianship is largely populated by women; again calling masculinity into question. This may be why Dom appears to be trying hard to develop a secure identity for himself by 'normalizing' the male librarian as an 'ordinary lad' - and 'normality' here is 'done' with reference to what he sees as traditionally working-class pastimes, physical appearance and bearing.

\section{How might working-class men come to be in female-concentrated occupations?}

There seems to be a paradox in the data in this regard. Working in femaleconcentrated occupations appears to create particular difficulties for working-class men in respect of their masculine identity, yet many working-class men find themselves in such jobs. One explanation might be that workingclass men are drawn to female-concentrated occupations for reasons other than their gender composition, and that these attractions may outweigh 
other considerations. A second might be that the processes through which higher status and higher-paid jobs, which are typically male-concentrated jobs, tend to exclude them. I will take these explanations in turn.

\section{Do working-class men choose occupations that are female-concentrated?}

The interview data suggest that for men in female-concentrated work their occupations offered three important features: job security, public-sector employment (in the case of the librarians and primary-school teachers, who were all working or intending to work in the public sector) and room to pursue interests and commitments outside work. It is interesting that a number of these men offered class-related explanations for the fact that these features were attractive. Job security was particularly important to those from working-class backgrounds, as Neil explains:

[A]nd it's there, the road to security is open, which is important, it's probably my working-class roots really.... The idea of a job, if not for life, for a considerable amount of time, is very appealing especially as a lot of my friends haven't got that benefit at all. (Neil, librarian)

The perceived security of employment in these jobs may be partly a function of the fact that they are usually carried out in the public sector, but there was evidence that public-sector employment was important for other reasons. Some of the working-class men in female-concentrated occupations expressed political views which, they explained, influenced the type of job that they sought:

[W]ell, these political views, if you like ... I wanted something that was a bit more, well, public sector and the aims that I could agree, but I've never fancied the idea of working my life to line some fat cat or director's pockets in some private company and that's always been constant. (Dom, librarian)

Dom identifies the attraction of public-sector values, but also articulates a point raised by three of the working-class respondents: that they specifically sought to avoid working in the private sector, which had, in their view, connotations of greed and exploitation.

A second issue to emerge here was working-class men's understanding of the place of work in their life. The notion that work might provide a longterm progression, social status and self-actualization is absent from the comments of the working-class men in the sample, and this is likely to inhibit the pursuit of career opportunities that provide these things. Indeed as Willis (1977) has explained, the need of some working-class people to preserve their identity by distancing themselves from such notions may lead to an active avoidance of the relevant opportunities. The following two quotes are 
illustrative. Peter discusses the 'alien' concept of the career and Neil explains how he sees the role of paid work in his life:

I mean it [career] has just never been a word in my vocabulary: you get a job you done a ... I have never had a career. I have never thought about a career: it is something that someone else did. I don't see it as something that my family did particularly. (Peter, librarian)

I want a good job, I want a decent job; something I don't hate, something that I quite enjoy would be a bonus, but something that at the end of the day is going to give me enough cash to do what I want in my own time, really, and I think that could be a hang up from my sort of working-class background, really. A lot of my family are like that, because they do dirty, dangerous jobs. You know, you do it because you want the money, really. (Neil, librarian)

Neil's comments reflect Parker's (1983) 'neutral' orientation to work in relation to leisure, which he (Neil) identifies as a class-based attitude. Both this and the 'oppositional' orientation that Parker associates with jobs such as those done by Neil's family contrast with the 'extension' orientation that Parker associates with 'professional' occupations, in which 'work signifies the meaning and fulfilment of life' (1983, p. 90). If not having an 'extension' orientation leads some working-class men to exclude themselves (or be excluded) from careers where this is perceived to be necessary, it may account for their presence in occupations where a 'neutral' orientation is perceived as the norm. If such occupations are also predominantly populated by women, this might then form part of an explanation for the presence of working-class men in female-concentrated occupations.

It is also possible that working-class men might weigh up the difficulties and advantages of entering female-concentrated occupations and then choose to enter them. However, there was no evidence of this in the men's accounts, and indeed, very little evidence at all that these men 'chose' to be there in the sense of selecting and pursuing a career from a range of alternatives. This was how many of the middle-class men in the male-concentrated occupations described it, but the overwhelming discourse for all the librarians and some of the teachers was around having 'ended up' in femaleconcentrated work:

I think that if you talk to any librarian ... the career's not usually something they planned. You get the odd one ... but it's usually a haphazard sort of thing: you don't know what to do; you go off and do something. (Neil, librarian)

[A]s I say, the reason that I said I should tell the truth [about becoming a librarian] is because - a big factor was - I just needed any kind of job. (Dom, librarian) 


\section{Why might working-class men be more likely to work in female-concentrated occupations?}

The interviews provided some interesting clues as to how men from different backgrounds came to be in particular occupations. The data show that many of the middle-class men were encouraged to seek out higher paid 'male' professions, were prepared for them and were provided with information on routes into them from an early age. Many of the working-class men were not:

I suppose that's the influence that school had on me, there was very little outside that ['the professions'] that you thought about going into. So I never remember any careers outside the sort of the established careers being suggested, so almost all my contemporaries have sort of gone to ... lawyers, bankers, doctors. (Mel, trainee solicitor)

I quite liked the idea of being a postman ... a milkman as well ... I realized that you could hang on and do A-levels. I could get an even better job, I could get something like, with the council, you know, a clerk or something in local government and that was what I was aiming for, really ... teachers at the sixth-form college said, 'have you thought about university?' and I remember it clear as day... I did a double take. (Dom, librarian)

Not only did the middle-class respondents reveal an understanding of which graduate careers offered higher status and rewards, they also demonstrated an understanding of the strategies required to ensure that they had access to them. Working-class men, in contrast, were less well equipped to play the 'careers' game'. This appeared to be a form of tacit knowledge in middleclass families which was detrimentally absent elsewhere: for example, Steve, a clerical worker, describes how his parents were 'lost as how to advise him'. Similarly, here Dom explains how his understanding had been that going to university would in itself be a path to a highly paid job:

It's frightening: I was so ill-informed in some ways, we didn't know anybody who'd been to university.... At the back of my mind I probably thought it was as if I was going to Oxford or something. I went to Hull, but I probably thought that when you get to university, get a degree, you come out and the world's your oyster. You're up in heaven, ICI, the chairman, and of course it's not like that. (Dom, librarian)

By contrast, Mel had been encouraged to choose and plan his career from an early age and developed an early awareness that attending university was a necessary, but not a sufficient, condition for achieving his aims:

And you were always at parent evenings at preparatory school, they used to be: 'is Mel saying anything when he's at home about what he'd like to 
do?' . . well I wanted to do law from the age of $11 \ldots$ and I made enquiries at the careers service at school to see whether it was going to be detrimental not to do arts subjects. (Mel, trainee solicitor)

Moreover, careers advice of this sort appeared to be a restricted and classbased commodity:

[T]here was a normal careers service at school, but it tended to be the: 'Do you want to work inside or outside?' — that basic career interview. (Peter, librarian)

We should also be aware that expectations around occupations are framed and legitimized by class background and that this may have an impact on the occupations to which it is considered acceptable to aspire. Here the contrast between what teaching meant in Mel and Niall's backgrounds is instructive:

I think we were talking the other day, every step the family takes is a step up the ladder and sort of, I suppose it works in social class that their parents ... [have] taken a step up in the social standing and then I suppose I'm the next on going into law. I mean, I don't necessarily see it like that, but that's the way they [my parents] look at it . . I suspect that that is what they [my parents] are referring to, they are sort of saying 'oh, it's taking you to the next sort of social bracket'. (Mel, trainee solicitor)

My dad was proud [when I became a teacher]. It was something he could tell people: he'd made something. He was a lowly builder and I was a teacher. (Niall, primary-school teacher)

For Mel, whose parents were teachers, taking a step up requires entry to one of the 'professions'. For Niall, whose father was a builder, becoming a teacher fulfils this criterion more than adequately.

\section{Towards an understanding of men's entry to female- concentrated occupations - incorporating class and gender}

The data illuminate the complex and contradictory ways in which men conceive of the notion of working in a female-concentrated occupation. Many of the respondents showed an acute and subtle awareness of the advantages (in terms of progression) and disadvantages (in terms of pay and prestige) of entering female-concentrated work. Many also talked at length and in detail about the perceived challenges to masculinity in female-concentrated work and it was clear that, all other things being equal, this would be a major disincentive to entering such work.

Indeed, the issue of men's entry to female-concentrated occupations is often framed as one of masculinity, both at the level of popular discourse and that of academic inquiry. The argument is that some men may be drawn to (or 
at least, less repelled by) female-concentrated work because they are less 'masculine', or differently 'masculine', from men who work in traditional male areas. However, if this were correct, one would expect men who worked in female-concentrated occupations to be more flexible about their masculinity than those who did not. As noted above, attempts to demonstrate this present an inconclusive picture and there are difficulties with the way in which masculinity is conceptualized and measured in some of these studies. It is also possible that different approaches to masculinity might be a consequence of one's presence in female-concentrated work, rather than being a cause of being there. My data do not suggest that men in female-concentrated occupations are less concerned about challenges to masculinity than are other men. On the contrary, the men who tended to speak at greatest length about issues of work and masculinity were those who worked in femaleconcentrated occupations.

There is therefore a need to move beyond an approach to this issue that rests solely on either human essence or agency. In this article I have suggested one way in which this can be done. I have argued that the presence of some men in female-concentrated occupations could be explained on the basis of the processes by which people are sorted into different occupations and differently valued occupations in a labour market that is segregated by gender and class. In other words, the movement of men into femaleconcentrated occupations operates at the confluence of two processes. The first are the processes which ensure that working-class men and women are less likely to reach higher-level occupations than middle-class men, even when educational qualifications are accounted for (Marshall et al., 1997). The second is the process by which women are disproportionately found in lowerstatus, lower-paid occupations than men; again when class of origin and qualifications are controlled for (Marshall et al., 1997). This particularly applies in the case of what Marshall et al. (1997) term 'salariat' jobs (such as the ones studied here), where women are disproportionately found in lowerlevel salariat jobs and men in higher ones (Marshall et al., 1997). In such a labour market men should be able to escape less-valued occupations on account of the advantages of their gender, but those men disadvantaged by their class (and indeed with other labour market disadvantages) may not be able realize this advantage, taking instead lower-status jobs mainly occupied by women.

This article does not demonstrate that men from working-class backgrounds are disproportionately found in female-concentrated occupations: the size and nature of the sample demand caution in making such generalizations. However this is an empirically resolvable issue and, as noted above, there is some support for my hypothesis from survey data (Lemkau, 1984; Lupton, 2003). A large-scale study across a range of occupations in the UK would make a useful contribution in this regard. What this study has shown is how this might work; in other words how the processes 
underpinning social mobility can lead men from working-class backgrounds to enter female-concentrated occupations, despite the masculinity 'difficulties' that result. The processes around the framing of expectations and the different meaning of work for people from different classes are well documented in the social mobility literature (Goldthorpe, 1987; Marshall et al., 1997) and are readily evident in the data presented above. This is not to suggest that masculinity should be conceived as being independent of social class - the data presented here, and the work of Collinson (1992), for example, clearly suggest otherwise - nor that gender is in some general sense subordinate to class in explaining the operations of the labour market. Instead, the results of this study suggest that class and gender need to be considered together in building an explanation for differences in the gender type of men's occupational destinations and the article has shown how this might be approached and understood.

\section{Acknowledgements}

The author would like to thank the editors and reviewers for their helpful comments and suggestions, and Professor Andrew Pendleton, Dr Ardha Danieli and Professor Suzan Lewis for their guidance and support throughout this research project.

\section{Notes}

1. The term, 'female-concentrated', used by Hayes (1989), is in my view preferable to some of the commonly used alternatives, such as 'female-dominated' (men may dominate, even when women are in the majority) and 'non-traditional' (the implication that occupational segregation is a matter of tradition is best avoided) and 'female occupation/women's work' which may, deliberately or otherwise, 'fix' the gender associations of particular jobs. There is no agreed system for determining what counts as a 'female-concentrated occupation'. Different researchers have used different relative proportions of men and women to allocate occupations in this way (Anker, 1998). Given women's relatively low labour-market participation rates, there is a case for arguing that occupations where women are in a simple majority should be so regarded. As this applies particularly across the range of 'professional' jobs from which the occupations in this study are drawn, this is how I have used the term in this article.

2. For stylistic reasons I omit the inverted commas which I might otherwise use to indicate my caution in using this term.

3. In relation to their distribution in occupations like nursing, personnel, teaching and librarianship overall.

4. However, Sargent (2000) has suggested, in his study of men in primary-school teaching, that avoiding roles involving close contact with small children may be better interpreted as part of a strategy by men to avoid allegations of child abuse. 
5. Collier shows how, in law schools, men's dress reflects, 'men's efforts to make their bodies conform to historically specific ideas of heterosexuality.' (1998, p. 42). One would expect this to be a strategy used by men in female-concentrated occupations, given the heightened challenge to masculinity there, but I am not aware of studies that specifically address this.

6. A dichotic listening test seeks to identify patterns of information processing in the brain by sending audible signals simultaneously to each ear. Men and women have been found to differ in their (relative) levels of left-brain and rightbrain activity as measured by these tests (Govier, 1998)

7. The occupational distribution of homosexual men has also been drawn on to shed light on the association between masculinity and occupation. This, too, has conceptual difficulties, not least around the meaning of the category 'homosexual' (see Connell's critique, 1987) and the presumed association of homosexuality with masculinity, or rather a lack of it - although there is a case that homosexual versions of doing masculinity depart from the hegemonic heterosexual ones which may underpin male advantage over women in employment. Solid evidence of a distinctive distribution of homosexual men in employment is sparse, though there is some evidence to suggest it exists (Carmichael, 1992, 1995; Chung and Harmon, 1994; Hewitt, 1995; Humphrey, 1999). However, as Humphrey (1999) has pointed out, this may be less a matter of occupational preference than a desire to avoid harassment in male-concentrated workplaces and the result of discrimination in others, particularly where working with children is involved.

8. These findings have nonetheless been challenged by Sheila Jacobs (1995) who found in her British study that the sex-typing of someone's first job affected that of subsequent jobs, providing support for a model of cumulative disadvantage for those in female-concentrated occupations.

9. The proportions of men in each of these occupations is as follows: primaryschool teaching; 14 per cent; librarianship, 41 per cent; human resource management, 43 per cent; law, 63 per cent; chartered accountancy, 70 per cent; computing, 85 per cent (Office for National Statistics, 2001). These proportions are not static and graduate intakes in law and accounting are no longer dominated numerically by men, even if this is the pattern throughout the profession as a whole. It is also possible to argue that occupations may be ideologically gendered in ways that cannot be directly read off from their numerical gender balance (Brittan, 1998).

10. Faisal identified himself as coming from a minority ethnic group. Elsewhere in the interview he refers to the impact of his ethnicity on his career preferences and outcomes. However, it is not possible to explore this within the scope of the current article.

11. I rely on my respondents' usually unprompted self-allocation to a social class category. I have not attempted to allocate them to one of the existing schemes of classification on the basis, say, of parental occupation. The apparent dualism that emerges (working class/middle class) reflects its usage in the discourses of my respondents - it was clearly the way they understood social class distinctions operating and it helped them make sense of their circumstances - rather than any preference on my part for such an approach to classification.

12. Henceforth referred to as 'working-class men', for convenience. The description refers to their social class of origin, not to their current occupational social class. 


\section{References}

Allan, J. (1993) Male elementary teachers: experiences and perspectives. In Williams, C.L. (ed.) Doing 'Women's Work': Men in Nontraditional Occupations, pp. 113-27. Sage: London.

Anderson, P. (1998) Choice: can we choose it? In Radford, J. (ed.) Gender and Choice in Education and Occupation, pp. 141-61. Routledge: London.

Anker, R. (1998) Gender and Jobs: Sex Segregation of Occupations in the World. International Labour Office: Geneva.

Barrett, F.J. (1996) The organizational construction of hegemonic masculinity: the case of the US Navy. Gender, Work E Organization, 3,3, 129-42.

Benton DeCorse, C.J. and Vogtle, S.P. (1997) In a complex voice: the contradictions of male elementary teachers' career choice and professional identity. Journal of Teacher Education, 48,1, 37-46.

Bhaskar, R. (1989) Reclaiming Reality: A Critical Introduction to Contemporary Philosophy. Verso. London.

Bradley, H. (1993) Across the great divide: the entry of men into 'women's jobs'. In Williams, C.L. (ed.) Doing 'Women's Work': Men in Nontraditional Occupations, pp. 10-27. Sage: London.

Brittan, D.M. (1998) The epistemology of the gendered organization (or, how do we know a gendered organization when we see one?). Paper presented at the Gender Work and Organization Conference, Manchester, January.

Brookhart, S.M. and Loadman, W.E. (1996) Characteristics of male elementary teachers in the U.S.A., at teacher education programme entry and exit. Teaching and Teacher Education, 12,2, 197-210.

Carmichael, J.V. (1992) The male librarian and the feminine image: a survey of stereotype, status and gender perceptions. Library and Information Science Research, $14,4,411-46$.

Carmichael, J.V. (1995) The gay librarian: a comparative analysis of attitudes towards professional gender issues. Journal of Homosexuality, 30,2, 11-57.

Carrigan, T., Connell, R. and Lee, J. (1985) Toward a new sociology of masculinity. Theory and Society, 14,5, 551-604.

Chung, Y.B. and Harmon, L.W. (1994) the career interests and aspirations of gay men: how sex-role orientation is related. Journal of Vocational Behaviour, 45,2, 223-39.

Cockburn, C. (1988) The gendering of jobs. In Walby, S. (ed.) Gender Segregation at Work, pp. 29-42. Open University Press: Milton Keynes.

Coffey, A. and Atkinson, P. (1996) Making Sense of Qualitative Data: Complementary Research Strategies. Sage. London.

Collier, A. (1994) Critical Realism: An Introduction to Roy Bhaskar's Philosophy. Verso. London.

Collier, R. (1998) 'Nutty professors', 'men in suits' and 'new entrepreneurs': corporeality, subjectivity and change in the law school and legal practice. Social and Legal Studies, 7,1, 28-52.

Collins, P. (1998) Negotiating selves: reflections on 'unstructured interviewing'. Sociological Research Online, 3,3, 1-18.

Collinson, D.L. (1992) Managing on the Shopfloor: Subjectivity, Masculinity and Workplace Culture. de Gruyter: Berlin.

Collinson, D.L. and Hearn, J. (1994) Naming men as men: implications for work, organizations and management. Gender, Work E Organization, 1,1, 2-22.

Collinson, D.L. and Hearn, J. (1996) Breaking the silence: on men, masculinities and managements. In Collinson, D.L. and Hearn, J. (ed.) Men as Managers, Managers as 
Men: Critical Perspectives on Men, Masculinities and Managements, pp. 1-24. Sage: London.

Connell, R.W. (1987) Gender and Power. Polity Press: Oxford.

Cross, S. and Bagilhole, B. (2002) Girls' jobs for the boys? Men, masculinity and nontraditional occupations. Gender, Work E Organization, 9,2, 204-26.

Dabbs, J.R., de la Rue, J.M.D. and Williams, P.M. (1990) Testosterone and occupational choice: actors, ministers, and other men. Journal of Personality and Social Psychology, $59,6,1261-65$.

Denzin, N.K. (1989) The Research Act: A Theoretical Introduction to Sociological Research Methods. Prentice Hall: London.

Deutscher, I. (1984) Asking questions and listening to answers. In Bulmer, M. (ed.) Sociological Research Methods: An Introduction. Macmillan: Basingstoke.

Department for Education and Skills (2001) Statistics for education. Available online at http:/ / www.dfes.gov.uk.

England, P. and Herbert, M.S. (1993) The pay of men in 'female' occupations: is comparable worth only for women. In Williams, C.L. (ed.) Doing 'Women's Work': Men in Nontraditional Occupations, pp. 28-48. Sage: London.

Floge, L. and Merrill, D. (1986) Tokenism reconsidered: male nurses and female physicians in a hospital setting. Social Forces, 64,4, 925-47.

Galbraith, M. (1991) Attracting men to nursing: what will they find important in their career? Journal of Nursing Education, 30,4, 182-86.

Goldthorpe, J.H. (1987) Social Mobility and Class Structure in Modern Britain: $2^{\text {nd }}$ Edition. Clarendon Press: Oxford.

Govier, E. (1998) Brainsex and occupation. In Radford, J. (ed.) Gender and Choice in Education and Occupation. Routledge: London.

Govier, E. and Bobby, P. (1994) Sex and occupation as markers for task performance in a dichotic measure of brain asymmetry. International Journal Psychophysiology, 18,3, 179-86.

Gutek, B.A. and Groff Cohen, A. (1992) Sex ratio, sex role spillover, and sex at work: a comparison of men's and women's experiences. In Mills, A.J. and Tancred, P. (eds) Gendering Organizational Analysis, pp. 133-50. Sage: London.

Hayes, R. (1986) Men's decisions to enter or avoid nontraditional occupations. The Career Development Quarterly, 30,3, 89-101.

Hayes, R. (1989) Men in female-concentrated occupations. Journal of Organizational Behavior, 10,3, 201-12.

Heickes, E.J. (1991) When men are the minority: the case of men in nursing. The Sociological Quarterly, 32,3, 389-401.

Hewitt, C. (1995) The socioeconomic position of gay men: a review of the evidence. American Journal of Economics and Sociology, 54,4, 461-79.

Humphrey, J.C. (1999) Organizing sexuality, organized inequalities: lesbians and gay men in public service occupations. Gender, Work E Organization, 6,3, 13451.

Isaacs, D. and Poole, M. (1996) Being a man and becoming and nurse. Journal of Gender Studies, 5,1, 39-47.

Jacobs, J.A. (1993) Men in female-dominated fields: trends and turnover. In Williams, C.L. (ed.) Doing 'Women's Work': Men in Nontraditional Occupations. Sage: London.

Jacobs, S.J. (1995) Changing patterns of sex segregation throughout the life-course. European Sociological Review, 11,2, 157-71.

Jome, L.M. and Tokar, D.M. (1998) Dimensional of masculinity and major choice traditionality. Journal of Vocational Behaviour, 52,1, 120-34.

Kanter, R. (1977) Men and Women of the Corporation. Basic Books: New York. 
Kerfoot, D. and Knights, D. (1993) Management, masculinity and manipulation: from paternalism to corporate strategy in financial services in Britain. Journal of Management Studies, 30,4, 659-77.

Kvande, E. (1998) Doing masculinities in organizational restructuring. Paper presented at the Gender Work and Organization Conference. Manchester, January.

Lemkau, J.P. (1984) Men in female-dominated professions: distinguishing personality and background features. Journal of Vocational Behaviour, 24,1, 110-24.

Lobel, T.E. (1994) Sex typing and the social perception of gender stereotypic and nonstereotypic behavior: the uniqueness of feminine males. Journal of Personality and Social Psychology, 66,2, 379-85.

Long, P. (1984) The Personnel Specialists: A Comparative Study of Male and Female Careers. IPM: London.

Lupton, B. (2000) Maintaining masculinity: men who do 'women's work'. British Journal of Management, 11, S33-S48.

Lupton, B. (2003) 'What kind of man are you?' - masculinity, social-class and men who work in female-concentrated occupations. Unpublished Ph.D. thesis, Manchester Metropolitan University.

McLean, H.M. and Kalin, R. (1994) Congruence between self-image and occupational stereotypes in students entering gender-dominated occupations. Canadian Journal of Behavioural Science, 26,1, 142-62.

Marshall, G., Swift, A. and Roberts, S. (1997) Against the Odds: Social Class and Social Justice in Industrial Societies. Oxford University Press: Oxford.

Morgan, D.H.J. (1992) Discovering Men. Routledge: London.

O'Heron, C.A. and Orlofsky, J.L. (1990) Stereotypic and nonstereotypic sex role trait and behaviour orientations, gender identity, and psychological adjustment. Journal of Personality and Social Psychology, 58,1, 134-43.

Office for National Statistics (2001): Labour Force Survey (Spring, 2001). Available online at http:/ /www.statistics.gov.uk.

Padfield, M. and Proctor, I. (1996) The effect of the interviewer's gender on the interviewing process: a comparative enquiry. Sociology, 30,2, 355-66.

Parker, S. (1983) Leisure and Work. Allen and Unwin: London.

Pringle, R. (1988) Secretaries Talk: Sexuality, Power and Work. Verso: London.

Pringle, R. (1993) Male Secretaries. In Williams, C.L. (ed.) Doing 'Women's Work': Men in Nontraditional Occupations, pp. 128-151. Sage: London.

Roberts, K. (1981) The sociology of work entry and occupational choice. In Watts, A.G., Super, D.E. and Kidd, J.M. (eds) Career Development in Britain, pp. 279-99. Hobsons Press: Cambridge.

Sargent, P. (2000) Real men or real teachers? Contradictions in the lives of men elementary teachers. Men and Masculinities, 2,2, 410-33.

Segal, B. (1962) Male nurses: a case study in status contradictions and prestige loss. Social Forces 41, October, 31-8.

Schwalbe, M. and Wolkomir, M. (2001) The masculine self as problem and resource in interview studies of men. Men and Masculinities, 4,2, 90-103.

Thompson, P. and McHugh, D. (1990) Work Organizations. Basingstoke: Macmillan.

Tokar, D.M. and Jome, L.M. (1998) Masculinity, vocational interests, and career choice traditionality: evidence for a fully mediated model. Journal of Counseling Psychology, 45,4, 424-35.

Williams, C.L. (ed.) (1993) Doing 'Women's Work': Men in Nontraditional Occupations. Sage: London.

Williams, C.L. (1995) Still a Man's World: Men Who Do Women's Work. University of California Press: London. 
Williams, C.L. and Heickes E.J. (1993) The importance of the researcher's gender in the in-depth interview: evidence from two case studies of male nurses. Gender $\mathcal{E}$ Society, 7,2, 280-91.

Williams, L.S. and Villemez, W.J. (1993) Seekers and finders: male entry and exit in female dominated jobs. In Williams, C.L. (ed.) Doing 'Women's Work': Men in Nontraditional Occupations, pp. 64-90. Sage: London.

Willis, P.E. (1977) Learning to Labour. Saxon House: Farnborough. 
Copyright of Gender, Work \& Organization is the property of Blackwell Publishing Limited and its content may not be copied or emailed to multiple sites or posted to a listserv without the copyright holder's express written permission. However, users may print, download, or email articles for individual use. 